\title{
Religious Quest for Sustainable Development: An Islamic Standpoint
}

\author{
Ahamad Faosiy Ogunbado \\ Faculty of Islamic Development Management ,Universti Islam Sultan Sharif Ali, \\ Brunei Darussalam \\ \{faosiy.ogunbado@unissa.edu.bn., tunbado@hotmail.com\}
}

\begin{abstract}
Scholars of various fields have taken interest in the Concept of Sustainable Development (SD) especially during the last few decades. From the mainstream literature, it is believed that the traditional development focused mainly on economic development and failed to address some issues such as the problem of inequalities, environment, and other things that are integral parts of the universe. Therefore, the concept of sustainable development (SD) emerged to cover the loopholes. It came to limelight after the publication of the report known as "Brundtland Report," or "Our Common Future" in 1987. The report defined the concept as "development that meets the needs of the present without compromising the ability of future generations to meet their own needs." However, this concept with all its golden promises also has its defects. Based on this background the paper tries to present religious perspective of the concept especially from Islamic point of view. In other to achieve its objective, the paper utilizes Qualitative research methodology, which based on content analysis on Al-Qur'an, Hadith and other literature. The result shows that Western perspective of the sustainable development only based on materialistic aspect and neglects the spiritual side. It also shows that the notion is not new from Islamic civilization. Above all, Islamic based sustainable development is considered as holistic or comprehensive which left no stone untouched.
\end{abstract}

Keywords: Religion, Sustainable Development, Islamic Standpoint

\section{Introduction}

The Concept of Sustainable Development (SD) is a common concept of the 21st century. Many researchers have developed their interest in it. It has become a theme of discussions for many and interdependent areas. Many conferences and summits have been staged at global as well as regional level since 1970s towards maintaining sustainable development. Sustainable Development has no consensus definition, scholars defined it according to their standing point but one of the most circulated definition in literature is given by "Brundtland Commission Report" thus: "the development that meets the needs of the present generation, without compromising the ability of the future generations to fulfill their need" [1].

Sustainability denotes that the concept is wider in scope than tradition impression of development which focus on economic prosperity. The major elements of sustainable 
development are social, economic and environmental which jointly serve as a bridge that links economic, ecology and religion or spirituality and ethics together. In other words, it calls for a holistic integrating of social development, economic growth and environmental improvement.

Furthermore, there is no specific definition of religion as well, due to its variety. It is defined as "an organized system of beliefs, ceremonies, practice and worship that centre on one supreme God, or the deity"[2]. It is also widely believed that religion is "collection of cultural systems, belief systems, and worldviews that relate humanity to spirituality and, sometimes, to moral values". However, whatever the differences they may have, many still shared some features in common. According to Al-attas, the term dīn which is generally understood to mean religion is not really tally which the concept in the west. However, the din (religion) Islam is perceived to be "the faith, beliefs and practices and teachings adhered to by the Muslims individually and collectively as a community and manifesting itself altogether as an objective while as religion called Islam"[3]. Islam quest for unity and harmony of the creations and this responsibility rests on human beings' shoulder as vicegerence. Therefore, Sustainable development from Islamic standpoint is a wide encompassing phenomenon that covers physical, mental and spiritual aspect of human being and environment as integral part of the universe or cosmos.

After the introduction, the paper sheds light on definition and history of sustainable development. It elaborates what is meant by sustainable development from deferent researchers and talks about how the term came into existence from mainstream literature. It further looks into the definition from Islamic perspective. The paper then talks about Islam and sustainable development. There, it discusses how the concept recognizes the human begins as actors or custodians and stewards upon all other creatures. It then elucidates Social Justice and Poverty Eradication. This is followed by Sustainable use of natural resources or environmental care. In relation to this, some other themes such as Land Development and Reclamation, water, air and animals preservation are discussed. Lastly, the paper discusses two important concepts from Islam which really support sustainable development project: the concept of moderation (wasatiyah) and Fitrah (Innate Nature).

\section{Result and Discussion}

\subsection{Definition and History of Sustainable Development}

The word "Sustainable" is a combination of two words "sustain" + "able". "Sustain" means "give support to", "to hold up", "to bear" or to "keep up". Then Sustainable is an adjective for something that is able to be sustained, i.e, something that is "bearable" and "capable of being continued at a certain level". All in all, sustainability can be defined as the process(es) by which something is kept at a certain level. The word sustainability comes from sustainable + ity [4]. Sustainability was used to describe an economy in equilibrium with basic ecology support system in the 1970s.[5].

Development is a complex, contested, and elusive term. However, according to Oxford English Dictionary means "the process of developing or being developed." or "an event constituting a new stage in a changing situation."[6]. In case of society or socio-economy system, it usually implies improvement either in the partial or general situation of the system. Development "is a process that creates growth, progress, positive change or the addition of physical, economic, environmental, social and demographic components"[7]. Repetto as it was cited by Zubair Hasan defines the concept as "the one that aims at managing all natural, 
human and financial resources of a country for increasing its wealth and welfare over a longrun." "It is a vector -a list of element $\mathrm{s}$ - that society seeks to maximize."[8].

Literature shows that the first form of development is always associate with the "economy" to form "Economic Development". Which is defined as "improvement of the way endowment and goods and services are used within (or by) the system to generate new goods and services in the numbers of the system"[9]. It is habitually used for increase in the per capital income of economy system. Therefore, it is obvious that the development here is focus on economic transformation rather than as a development process per se. In other words, there is need for a comprehensive transformation or growth.

Furthermore, Sustainable Development, literally "refers to maintaining development over time" There is no agreed or universal definition for "sustainable Development". Hundreds of definitions are in circulation with divergent interpretations and thousand ways of implementation. For instance, Conway defines SD as "the net productivity of biomass (positive mass balance per unit area per unit time) maintained over decades to centuries" [10]. Turner describes it thus " in principle, such an optimal (sustainable growth) policy would seek to maintain an "acceptable" rate of growth in per-capita real incomes without depleting the national capital asset stock or the natural environmental asset stock" [11]. To The International Union for Conservation of Nature (IUCN) the term means "improving the quality of life while living within the carrying capacity of supporting ecosystems" [12]. However, the most common cited is the one given by the Brundtland Commission which defines it as "a development that fulfills the needs of the present generation, without compromising the ability of the future generations to fulfill their need"[1].

According to Hashim Kamali, the history of concept of sustainability and sustainable development can be traced to the 1960s "due to heighted appreciation over crucial issues of survival for the whole humanity"[5]. Efforts has been made towards maintaining sustainable development through summits, establishment of rules, laws and regulations at global and regional levels. One of the earliest attempts globally was the Stockholm conference in 1972.

Furthermore, United Nation (UN) formed an independent group of 22 people from developing and developed world in 1984. The task of this group or commission was to identify long-term environment strategies for the global community. The report of this commission was published in 1987 and known as "Our Common Future" or "Brundtland Report," It is widely accepted that this brought the SD into the political arena of global or international development thinking. The report of the commission served as basis of the UN conference on environment and development, "the Earth Summit" in Rio de Janeiro, Brazil in 1992. It was considered the largest ever international conference held with comprehensive attempt. 116 head of states or governments and over 8000 delegates attended. A key outcome of the summit was the "Agenda 21" document detailing the means of achieving sustainable development at the onset of $21^{\text {st }}$ century. Moreover, in 1997, about 200 countries signed the Kyoto Protocol which includes 28 articles and more focus on climate change.

In 2002 there was another "UN World Summit on Sustainable Development (WSSD) in Johannesburg, South Africa. It was aimed to strengthen the global commitment towards achieving "Sustainable Development".[13], [14]. There was a new understanding of the complex interdependencies of economic, social and environmental development in addition to the political challenges of Sustainable Development. Moreover, three sets of goals were established (1) the short -term for 2015, which is called goals of the Millennium Declaration of the United Nation. (2) The two-generation goals for 2050 of the Sustainability Transition of the Board on sustainable Development and (3) Goals of the Great Transition of the global Scenario Group, which is the long-term goal beyond 2050. In the same year, (2002). The 
International Law Association Committee on the legal aspects of sustainable development made another declaration which includes 7 principles. Some of these principles are the sole functions of the states as the actors to effectuate sustainable use of natural resources, the principle of equity and poverty eradication, the principle of common but differentiate responsibility.

\subsection{Definition from Islamic Perspective}

As it can be seen from Western perspective of the sustainable development. The concept has no agreed definition from Islamic standpoint as well. However, it is said to be "focuses on improved living and future prospects for all by way of wise and calculated investments in the present." [15]. It is also seen "as the mission of providing basic human needs for current times and the future, both material and spiritual; including the right of man throughout time and place to benefit from moral, cultural and social development" [15], [16]. It is also said to be "a long-term perspective concerned with the interests and right of the future generations, as well as of people today" [5]. It is defined as "a situation where the specified vector must increase over time without hinting the limit" [8]. One of the most common cited definition of Sustainable development from an Islamic perspective is given by Muhammad Nouh as "a multi-dimensional process that seeks to strike a balance between economic and social development on one side, and the environment on the other. It seeks for humans to use resources in the best possible way, accounting for the environment upon which those resources rely" [17].

It was learnt that series of steps have been taken in the past towards the Islamic approach for foster sustainable developments. However, it was in 2000 that the original draft of the first Islamic statement on sustainable development was produced at the International Environment Forum from an Islamic perspective in Jeddah, Kingdom of Saudi Arabia between 23-25 Octobers of the year. It was gathered that the principal aim and objective of the conference was to introduce Islamic civilizations notion on the conservation of the environment through divinely inspired concept of sustainability to the world. This Jeddah Declaration (adopted by OIC) was formally presented at World Summit in Johannesburg between August 26 to September 42002 as the "General Framework of Islamic Agenda for Sustainable Development."[18].

\subsection{Islam and Sustainable Development}

The notion of Islamic sustainable Development first and foremost recognizes the human beings as actors. Humans were created to serve as custodians and stewards upon all other creatures. They were created as vicegerents or Khulafah (Khalifa) on the earth. Although the Angels were not satisfied when they were told that man (Adam) will be created. They mentioned that human beings will be doing different kinds of injustice or mischief "fasad" on the earth but Allah answered them that HE knows what they do not know. Allah says:

"Behold thy Lord said to the angels: "I will create a vicegerent on earth."

They said "Wilt thou place therein one who will make mischief therein and shed blood? Whilst we do celebrate Thy praises and glorify Thy holy (name)?" He said: "I know what ye know not." (Surah al-Baqarah (2):30) [19].

When Allah says that HE knows what the angels did not know, one of these knowledge is that the creation of the man is for the purpose of worshiping Allah as it can be seen from the 
verse "I have only created Jinns and men, that They may serve Me." (Surah Adh-Dhariyat (51):56).[19]. Afterwards, they will return to HIM and be rewarded for their trusteeship. Allah also says: "On the earth will be your dwelling place and your means of livelihood for a time." (Surah Al-Baqarah (2): 36 and Surah Al-Anfal (7):24. [19]. That is to say Allah has created all what human begins need to sustain their life and they should utilize it and preserve it for the future generation that are coming behind them. The next paragraph will talk about the social justice and poverty eradication. While subsequent paragraphs will also elucidate the environmental care

\subsection{Social Justice and Poverty Eradication}

Islamic sustainable development is buttressed by the Islamic conception of ownership which makes human beings or individuals to be the owner of what he or she accumulates. After been placed as an authority on the earth there are also abundance wealth to cater for their needs. Al-Quran says: "It is We who have placed you with authority on the earth, and provided you therein with means for the fulfillment of your life: small are the thanks that ye give". Surah Al-Araf(7):10. [19].

Furthermore, Islam strongly rejects poverty and perceives it as threats to the faith, character, thought and to the society in general. Prophet says: "it is very near that poverty may turn itself into infidelity".[20]. He also used to pray against it [21]. Therefore, all able bodied individuals are enjoined to work and earn a lawful living. This is the first step in poverty eradication which sustainable development calls for. Aadam (a.s) the first man on the earth who was given the banner of caliphate on the earth was a farmer his children Qabil and Habil were also famer and hunter. Prophet Idris (a.s) was a tailor, Prophet Nuh and Zakariyya (a.s) were carpenters, Prophet Daud (a.s) was a blacksmith, and Prophet Moses (a.s) was a shepherd while Prophet Muhammad (s.a.w) was a trader and cattle rearer [21], [23]. Most of the Prophets if not all were shepherd and this can be seen from the following Hadith:

"The Prophet said, "Allah did not send any Prophet but shepherd sheep." His companions asked him, "Did you do the same?" The Prophet replied, "Yes, I used to shepherd the sheep of the people of Mecca for some Qirats." (Bukhari, Book 3, Volume 36, Hadith 463) [21].

Furthermore, all the early companions of the prophet were engaged in one labour or the other, Abubakr Al-Siddiq, Uthman bin 'Afan, and Abdulraman bin 'Auf were all traders while 'Umar bin Khatab was shepherd. There are numerous hadith encouraging Muslims to develop themself financially through lawful earnings hadith says:

"The Prophet said, "Nobody has ever eaten a better meal than that which one has earned by working with one's own hands. The Prophet of Allah, David used to eat from the earnings of his manual labor."(Bukhari, Book 3, Volume 34, Hadith 286) [21].

Also

"Allah's Apostle said, "By Him in Whose Hand my life is, it is better for anyone of you to take a rope and cut the wood (from the forest) and carry it over his back and sell it (as a means of earning his living) rather than to ask a person for something and that person may give him or not." (Bukhari, Book 2, Volume 24, Hadith 549) [21].

Also 
"If God provides anyone of you with an opportunity for earning a livelihood, let him not leave it unexploited until it is exhausted or becomes disagreeable to him." (Sunan ibn Maja. Vol. 8:2) [23].

Also

"He who refrains himself from begging, making efforts for family member and being kind to the neighbours searches livelihood lawfully and will meet with God with such a face which will bright like full moon" [24].

Besides encouraging seeking lawful earning as a major step to eradicate poverty and level the gap of inequalities, Islam also put other mechanisms in place to take welfare of the poor, or what can be called Social justice. This is where social and economy aspect of sustainable development meets. The said mechanisms includes, sadaqah, صدقة (charity), infaq إنفاق (voluntary spending), ihsan إحسان (benevolence), Waqf وقف (Charitable endowment) etc. Above all, Zakah زكاة (Poor due) is made as one of the five pillars of Islam, which is compulsory of every citizen who fulfil the nisab. Zakah purifies wealth and mind or heart of the payer while it increases the love of the payer in the mind of the receivers. In order for Abubakr to uphold the sustainability development of the first Islamic Society. He waged war against those who refused to pay zakah to the nation after the demise of the Prophet. History records that that was the first major decision he took as a Caliph.

This is to ensure the redistribution of the resources in the society to meet social justice or equity and not too concentrated in hand of few people (Surah Al-hashr (59):7), [19] as it can be seen in the Capitalist system. The system that promotes individualism and encourages maximaixation of wealth without considering the means. This is what gives rise to interest rate which is totaly prohibited in Islam. The wealth of the entire planet has been controled by the very few capitalists.

Furthermore, nobody can attain the level of virtue as a true believer, if he or she does not spend from what he accumulated through right channel. The Qur'an says: "By no means shall ye attain righteousness unless ye give (freely) of that which ye love; and whatever ye give of a truth God knoweth it well."(Surah Al-Imran (3):92), [19]. This is in relation with another verse where Allah commands modest justice, benevolence with fairness and frowns against the injustice. It also promotes Islamic brotherhood (Ukhwwah) in rendering assistant to the kith and kin, neigbours, and wayfarers and so as to achieve a sustainable society which Islamic Sustainable development demanded. Qur'an says:

"God commands justice, the doing of good, and liberality to kith and kin, and He forbids all shameful deeds, and injustice and rebellion: He instructs you, that ye may receive admonition".(Surah Al-Nahl (16):90.), [19].

\subsection{Social Justice and Poverty Eradication}

"We have honoured the sons of Adam; provided them with transport on land and sea; given them for sustenance things Good and pure; and conferred on them special favours, above a great part Of Our Creation." (Surah Alisrai(17):70.) [19].

From the verse, it is obvious that Allah has really honoured the vicegerents that HE created on the earth and has created other creatures in the universe to be under their control. To use them prudently and manage them diligently and extremely well so as to sustain them -present generation- and the future generation. 


\subsubsection{Land Development and Reclamation}

Land is categorically mentioned in the above verse and other 165 places across 52 chapters in the Qur'an. Its usefulness and benefit are discussed. 65\% stipulated its usage while 20\% talked about its management [25]. Human beings were created from the land, live on it and will also be buried on it to be raised up from it on the day of resurrection for the judgment. (Surah Nuh (71):17-19.; Surah Ta ha (20): 55), [19] There are numerous verses that indicate the land as origin of human beings. "..It is He Who hath produced you from the earth and settled you therein: then ask forgiveness of Him, and turn to Him (In repentance)."(Surah Hud (11):61 [22]. Likewise, he has created everything on earth for them. (Surah Al-Baqarah (2):29), [19]. So it is one of the vital factors of production. Allah says:

"It is He Who has made the earth manageable for you, so traverse ye through its tracts And enjoy of the Sustenance which He furnishes: but Unto Him is the Resurrection." (Surah Al-mulk (67):15.) [19].

As Human beings are created from the earth/land, and be custodians of all the creatures on it, there must be a proper and quality management [26]. There are many resource management and welfare institutions created in Islamic history to cater for sustainability objective in economy as well as society. (1) Land reclamation or revival: - under Shar'ah, whoever reclaim un-owned barren land, cultivating it and become useful. Such a person becomes its lawful owner. This become a strong incentive that lure people to invest in sustainable use of land. (2) Natural Reserve (hima):- this is a protected land where gazing, housing or industrial development are restricted. It is reserved as public property. Such reserved can be used to build "national parks" for wildlife preservation and also as a "land mark." Prophet Muhammad (s.a.w) established such a reserved zone in Madinah likewise the early caliphs (r.a) emulated the practice. (3) Land Reserves:- it is right of the authority to deny the private companies or individuals or agencies from development that can lead to environment degradation or destruction. (4) Public Land Grant:- authority can grant un-owned land to individuals, agencies or companies for the purpose of development which is sustainable. This is called iqta' in shari'ah. (5) Charitable Endowment:- Individuals as well as institutions can participate in preservation, conservation and sustainable development of land through waqf. The waqf fund can be used as effective tools for environmental protection as well as socioeconomic development. [5], [27], [28].

Furthermore, development of the land through cultivation or agriculture or growing crops or plant is highly encouraged in the religion. In other words, the act of planting trees and preventing deforestation is highly commended in Islam. Prophet Aadam (a.s) and his earliest sons were personally engaged in this act as it has been mentioned earlier. Moreover, plants are also useful in preventing land from water and wind erosions, other usefulness beside food and nutrition includes medicines, oils, wax, perfume, timber, fuel and energy (fire). Beside the holy Qur'an there are numerous hadith of the Prophet Muhammad (s.a.w) encouraging the act as a sustainable development. Hadith says:

Allah's Apostle said, "There is none amongst the Muslims who plants a tree or sows seeds, and then a bird, or a person or an animal eats from it, but is regarded as a charitable gift for him." (Bukhari ,Book 3, Volume 39, Hadith 513) [21].

Also

"The Prophet made a deal with the people of Khaibar that they would have half the fruits and vegetation of the land they cultivated." (Bukhari ,Book 3, Volume 39,Hadith 522) [21]. 
Also

"Allah's Apostle gave the land of Khaibar to the Jew's on the condition that they work on it and cultivate it, and be given half of its yield." ( Bukhari ,Book 3, Volume 39, Hadith 524) [21].

Also

The Prophet said, "He who cultivates land that does not belong to anybody is more rightful (to own it)." 'Urwa said, "Umar gave the same verdict in his Caliphate." (Bukhari ,Book 3, Volume 39, Hadith 528) [21]

Also

"It is a blessed act to plant a tree even if it be a day before the end of the world" [29].

and

"If any of you has a date sapling on Doomsday, he should (still) plant it—if possible" [29].

\subsubsection{Water Preservation}

This is another vital natural resources which should be preserve by human beings. It is mentioned 106 times in 49 chapters of the holy Qur'an. 88\% talked about its usage and benefits. $2 \%$ tabled the care of the water while $10 \%$ devoted for both.[25]. It is categorically stipulated that every living creatures were created from water. That is to say water is the origin of life. Thus, indicates the significant of water in the ecosystem-which is community of living and non-living component of the environment interacting as a system. All creatures, humans, Animals and plants depend on water for their survival and sustainable existence.

Allah reminds humans to appreciate HIS favour through water which they drink and the one sent down from the sky then rejuvenates the soil or helps the plants to grow. Both humans and animals will get crops and grasses or vegetables to eat and the food chain continues and sustains through the rain. Where there is scarcity of rain, there is water in river or sea to be used as irrigation. Water animals like fish will also continue to live and grow and serve humans. This is one of the signs of existence of Allah, the Sustainer. Al-Qur'an says:"See ye the water which ye drink? Do ye bring it down (in rain) from the cloud or do We? Were it Our will, We could make it salt (and unpalatable): Then why do ye not give thanks?" (Surah Al-waqi'a (56):68-70) [19].

"It is He Who sends down rain from the sky: from it ye drink, and out of it (grows) the vegetation on which ye feed your cattle. With it He produces for you corn, olives, date-palms, grapes, and every kind of fruit: Verily in this is a sign for those who give thought." (Surah Al-Nahl (16):10-11) [19].

"Then let man look at his food, (and how we provide it). For that We pour forth water in abundance, And We split the earth In fragments, And produce therein corn, and grapes and nutritious plants, and olives and dates, And enclosed gardens, dense with lofty trees, and fruits and fodder. For use and convenience to you and your cattle." (Surah 'Abasa (80):24-32) [19].

“....And (further), thou seest the earth barren and lifeless, But when We pour down rain on it, it is stirred (to life), it swells, and it puts forth every kind of beautiful growth (in pairs)." (Surah Hajj (22):5) [19]. 
Therefore, it is the role of mankind to properly managed water and natural resources contained, to sustain their life, enjoying the benefits while taking into the consideration the right of the others and on-coming generations, by preserving it. Prevent the wasteful overuse of the resources. Human beings have equal rights to the usefulness of the water. Therefore, the water of seas and rivers is not the property of individuals. It is the duty of the government to construct dam or irrigation system for the benefit of all. It was reported that Prophet Muhammad instructed his followers to conserve the water even in performing ablution at the river bank. He says: "Do not waste water even if performing ablution on the bank of a fastflowing (large) river." [30]. He led by example and used to perform his ablution with one mudd of water (0.6 litre) and observed his birth with one su'up to five mudd (2.5-3.5 litres) [18].

\subsubsection{Air Preservation}

Preservation and conservation of air is equally paramount for the continuity of life. All living creatures, humans, animals and plants need air for their survival. It is mentioned in 24 times across 18 chapters in the Qur'an, $75 \%$ discussed the usage while $25 \%$ is about care of the air. Al-Qur'an also elucidates other duties of the wind in facilitating lives [25]. Fresh oxygen which tress exhale is useful for mankind and animals and thus maintain ecological balance. In addition, it is wind that helps in pollination and formation of clouds that cause rain. Al-Qur'an says:

"And We send the fecundating winds, then cause the rain to descend from the sky, therewith providing you with water (in abundance), though ye are not the guardians of its stores" (Surah Al-Hijr (15):22) [19].

Environment should be kept clean. Waste burning should be prohibited or at least put some measure in place to control it and to avoid unnecessary air pollution which can cause damage to the creatures. Air pollution is capable of causing haze as well as global warming. Islam as a religion of peace prohibits release of dangerous chemicals or any other pollutants into the air or river-sea so as to prevent environmental degradation for the benefit of the present and future generation. Waste burning or releasing dangerous chemical is harmful. A legal maximcum-hadith says: "Harm may neither be inflicted nor reciprocated" [23].

\subsubsection{Animal Preservation}

Animals are other important element in the cosmos. They are integral part of biodiversity which must be preserved, to maintain the ecological balance. Islam as a religion strongly demands their conservation. They were also given special recognition in the holy Qur'an. They were mentioned 102 times in 40 chapters. $71 \%$ discussed about usage of animals while $7 \%$ talked about adequate treatment of the animal, the rest $21.5 \%$ commented on both [25]. There are even some chapters that are named after some specific animals such as cow, elephant, cattle, bee and spider. They are servient to human beings but at the same time must have pleasant relation with them, because they are creature like human beings. Al-Qur'an says: "There is not an animal (that lives) on the earth nor a being that flies on its wings but (forms part of) communities like you." (Surah Al-An'am (16):38) [19].

There are many benefits which human begins derive from animals. Besides being source of food and nutrition, they provide wools and leather which are used in manufacturing many things. Some of them are used as a mode of transportation, likewise used to produce 
medicine, perfume, pasture and protection. They should be preserved to sustain their usefulness and also develop them for the consumption of future generation. Al-Qur'an says:

"And cattle He has created For you (men) : from them ye derive warmth, and numerous benefits, and of their (meat) ye eat.\# And ye have a sense of pride and beauty in them As ye drive them home in the evening, and as ye lead them forth to pasture In the morning.\# And they carry your heavy loads to lands that ye could not (otherwise) reach except with souls distressed : for your Lord Is indeed Most Kind, Most Merciful.\# And (He has created) horses, Mules, and donkeys, for you To ride and use for show; And He has created (other) things of what ye have no knowledge." (Surah Al-An'am (16):5-8) [19].

From religion aspect animals are also worshiping their Lord (Creator), even for this reason, they should be preserved so as to continue their worshiping as their nature demands or prescribes. Al-Qur'an says:

"Seest thou not that it is God whose praises all beings In the heavens and on earth do celebrate, and the birds (of the air) with wings outspread? Each one knows Its own (mode of) prayer and praise. And God knows well all that they do. (Surah Al-Nur (24): 41) [19].

Animals as it can be seen are part of the universe which Islam calls for their development to accommodates and sustains both present and future generation. Religion put many steps in place as tools to animals' sustainable development. One is to show them mercy. Even though it is permissible to slaughter animals for consumption and purpose of religion or sacrifices to Allah as in eid al-hadiah. It is commanded that one should use a sharp knife so as to relieve animals from suffering. In light of this, electric shock is prohibited as it causes suffering to animals before they finally die. Killing animals without eating or for any other unlawful purpose are tantamount to destroying natural resources, Islam rejects such behaviour. Islam prohibits cruelty to animals and punishment awaits whoever indulge in such an act. There are many Hadiths to this effect. It says:

"Those who are merciful will be shown mercy by the Merciful. Be merciful to those on the earth and the One above the heavens will have mercy upon you" [30].

Also

Verily Allah has prescribed proficiency in all things. Thus, if you kill, kill well; and if you slaughter, slaughter well. Let each of you sharpen his blade and let him spare suffering to the animal he slaughter" [31].

Also

"The Prophet said, 'A woman entered the (Hell) Fire because of a cat which she had tied, neither giving it food nor setting it free to eat from the vermin of the earth." (Bukhari, Volume 4, Book 54, Number 535) [21].

Also.

The Prophet said, "A man saw a dog eating mud from (the severity of) thirst. So, that man took a shoe (and filled it) with water and kept on pouring the water for the dog till it quenched its thirst. So Allah approved of his deed and made him to enter Paradise." (Bukhari, Volume 1, Book 4, Number 174) [21]. 


\subsection{Concept of Moderation (al-wasatiyyah), in Islam}

One of the concepts to ensure the efficiency of Sustainable Development in Islam is the Concept of Moderation or Middle path known as (al-wasatiyyah), which means the "quality of being moderate and avoiding extremes," or "to be within limits that are not excessive. Islam is a moderate religion as Qur'an says: "And thus We have made you a moderate Ummah (nation), so that you should be witnesses over the people, and the Messenger a witness over you" (Surah Al Baqarah (2): 143), [19]. The religion requests cling to it in all undertakings, eccentricity, extremism, affectation and exaggeration are all disapproved [32]. In dealing with usage of natural resources water for example one should moderately use it for any purposes even in ablution as mentioned earlier. Land developers should not go extreme in cutting or destroying the trees for housing or any other purpose. In buying food items, there should be moderation less leads to food waste. Animals also are undeniable part of biodiversity which are subservient to human use. One should be moderate in using them as a means of transportation or slaughtering for food. Killing without any legitimate reason is a crime against nature and waste of natural resources. In spending one's wealth, it shouldn't be in the manner of a spendthrift. In short, extravagance in using bounty of Allah is rejected and is tantamount to destroying Allah's creature or handwork. Engaging in such behaviour is called Israf, while Musrifin are brothers of Shaytan. (the accused one). AlQur'an Says:

"O Children of Adam! Wear your beautiful apparel at every time and place of prayer: eat and drink: But waste not by excess, for Allah loveth not the wasters." (Surah Al-araf (7): 31.) [19].

Also.

"And render to the kindred their due rights, as (also) to those in want, and to the wayfarer: But squander not (your wealth) in the manner of a spendthrift.\# Verily spendthrifts are brothers of the Evil ones ; and the evil one is to his Lord (Himself) Ungrateful." (Surah Al-Israi (17): 26-27). [19].

\subsection{Concept of Fitrah (Innate Nature)}

Concept of Fitrah is another concept that really supports Sustainability Development in Islam. Fitrah is majorly translated as "Innate nature", "Original Disposition" or "Natural Constitution" Ibn Achour defines it as "a specific order encompassing all dimensions of the human personality or the state in which God created the human species free from all frivolity and bad habits". [33]. According to Ibn Taymiyyah, fitrah is the divine order in every created being and God's creation of the body and the intellect. He also considers it "as the set of qualities, characteristics, attributes, in which God created humans." [34], [15]. It is also implies the primordial covenant of Allah in the pre-existent world, in which Allah had with the children of Adam. Thus: "Am I not your Lord (who cherishes and sustains you)?"- They said: "Yea! We do testify!."( Surah Al-araf (7): 172) [19]. Therefore, concept of fitrah necessitate adherence to the nature, there shouldn't be deformation in any form to the Allah's design. Al-Quran says:-

"So direct your face toward the religion, inclining to truth. [Adhere to] the fitrah of Allah upon which He has created [all] people. No change should there be in the creation of Allah. That is the correct religion, but most of the people do not know." (Surah Al-rum (30): 30) [19]. 
Furthermore, Islam as a religion of fitrah indicates that the universe is created in a state of natural equilibrium, full of natural resources to sustain it life. There should be integration and spiritual interconnectivity between all these creatures. The concept authenticates sustainable development which calls for lack of deformations or distortion to any parts of the universe's family.

\section{Conclusion}

The paper is all about the religious quest for sustainable development. There are different religions if we go by the definition of religion from western perspective. However, the paper limits itself to religion $(d \bar{l} n)$ of Islam. Sustainable Development is meant to be "the development that meets the needs of the present generation, without compromising the ability of the future generations to fulfill their need". The paper made it clear through the history of SD that there were many conferences held both at regional and global level prior to Rio declaration on environment and development in 1992. But the phrase as it has been used today came to public eye through the "Brundtland report" or "Our Common Future" published in 1987.

The paper declares human begins as actors to play greater role in the concept. It further explains the social justice and poverty eradication given some mechanisms which Islam as a religion put into place to foster its actualization. The paper also talks about the sustainable use of natural resources such as land and water. Declaring that all living things were created from water and therefore they must be preserved. It also discovered that Animals are a family of cosmos like human beings. Thus, they also must be conserved. All in all, there must be harmony among the creatures and all must be preserved to meet the innate nature (fitrah).

All the arguments and evidences are produced from the Qur'an and Hadith which were considered as primary sources in Islamic literature, which some other Islamic literatures are also consulted. Therefore. It is learnt that the notion is not new from Islamic perspective as Prophet Muhammad (s.a.w) had practiced it 1442 years ago and instruct the coming generation to follow his practice. Sustainable development is also an act of worship (ibadah) which will be rewarded hereafter. In a nutshell, Islamic based sustainable development is considered as holistic or comprehensive which left no stone untouched.

\section{References}

[1] WCED. Report of the World Commission on Environment and Development. Oxford University Press. P.43. (1987).

[2] The World book encyclopedia, vol 16:197 (2009).

[3] Al-Attas, S.M.N. (1913) Islam and Secularism. Kuala Lumpur: International Institute of Islamic thought and Civilization (ISTAC). (1993)

[4] https://youmatter.world/en/definition/definitions-sustainability-definition-examplesprinciples/ accessed on 8-august-2020.

[5] Kamali, Mohammad Hasim. Focus Islam and sustainable development. Islam and Civilisational Renewal . (n.d)

[6] Oxford English Dictionary.

[7] https://www.sid-israel.org/en/Development-Issues/What-is-Development. 
[8] Zubir Hassan. Sustainable Development from Islamic Perspective : Meaning, Implications and Policy Concerns. JKAU:Islamic Economics, vol. 19 No.1pp3-18. (2006).

[9] Bellu, Lorenzo G. Development and Development paradigms: A (reasoned) review of prevailing visions. Easypol Resources for Policy Making.(2011) Pg. 3. http://www.fao.org/3/a-ap255e.pdf. Accessed 4-August-2020.

[10] Conway, G. R. 'The properties of agroecosystems', Agricultural Systems, 24, pp. 95117. P.96. (1987)

[11] Turner, R.K. Sustainable Environmental Management, Belhaven, London. P.12. (1988).

[12] Cited in Al-Jayyousi, O.R. (n.d). Islam and Sustainable Development: New worldview. P. 12. www.gowerpublishing.com/isbn/9781409429012 Assessed 2-august-2020

[13] Elliott, Jennifer A. An Introduction to Sustainable Development: The Developing World. New york: Routledge. Pp. 8-9. (2013).

[14] Oran Astrom, Z. H. Paradigm Shift for sustainable Development: The contribution of Islamic Economics. Journal of Economic and social Studies. Vol.1 no.1 Jan. 2011. Pg.73-82. (2011).

[15] Benaouda Bensaid. Crossroads Between Muslim Spirituality And Environmental Sustainability. Jurnal al-Tamaddun, Bil 13 (1), 2018, 65-81. (2018).

[16] Yahyawi \& Aqili. Al-Tanmiyyah wal-Masuliyyah al-Ijtimaiyyah min al-Manzur alIslami, 122). (n.d). http://iefpedia.com/arab/wp-content/uploads/2012/11. Retrieved June 4th 2017

[17] Noah, M., "Sustainable Development in a Muslim Context". Exploring Synergies between Faith Values and Education for Sustainable Development. Pp: 39-43. (2012).

[18] Ansari, Abdul Haseeb. Jamal, Parveen \& Osen,i Umar. "Sustainable development: Islamic dimension with special reference to conservation of the environment," Advances in Natural and Applied Sciences, Vol. 6, No. 5, 607-620. . (2012).

[19] 'Ali, A Y. The Meaning of the Holy Qur'an, new edition with revised translation, (commentary and newly complied comprehensive index. Maryland: Amana Publication. (2006).

[20] Qouted by Yusuf Al-Qardawi, Economic Security in Islam, translated by Muhammad Iqbal Siddiqi. Lahore: Kazi Publications. (1981).

[21] Shahih Bukhari.

[22] Ogunbado, A. F. "Mechanisms of Poverty Eradication: An Islamic Perspective". The Islamic Quarterly, Vol. 55, No. 4, pp. 295-315. (2011).

[23] Sunan ibn Maja. Riyad: Sharikah at-Tibaah al-Arabiyah as-Saudiyah. Vol. 8:2. (1984).

[24] Al-Ghazali, Abu Hamid. Ihya Ulum-id-din, Translated Fazlul Karim. New Delhi: Islamic Book Service. (1991).

[25] Helfaya, A.; Kotb, A \& Hanafi R. Quranic Ethics for Environmental Responsibility: Implications for Business practice. Journal for Business ethics. 1-46. (2016).

[26] Ogunbado, A. F. \& Al-Otaibi A. M. “Is Quality Management an Islamic Value?” IOSR Journal of Business and Management, (IOSR-JBM). Volume 8 Issue 3 Pp. 06-13. (2013).

[27] Ahmed, U. Mustafa, O. M. \& Ogunbado A. F."Examining the Traditional Waqf-Based Financing Methods and Their Implications on Socio-Economic Development”. IOSR Journal of Business and Management, (IOSR-JBM). Volume 17 Issue 2. Ver.1 Pp. 119125. (2015). 
[28] Ahmed, U., Mustafa, Omar. M., Ogunbado, A. F. \& Norzaidi Mohd Daud. Examining the Perception of Muslim Community in Uganda on Waqf and its Role on SocialEconomic Development”. Middle-East Journal of Scientific Research 23(6): 11731180. (2015).

[29] Quoted in Qadir, Junaid \& Zaman, Asad (2018) Sustainable Development Viewed From The Lens Of Islam. International Journal of Pluralism and Economics Education 10(1) (2018).

[30] Tirimidh, No 427.

[31] Al-Nawawi, n.d, Hadith no.17.

[32] Ogunbado, A. F., Ahmed, U. Balogun A.D. The Significance of Islamic Spiritual Ethics in Human Personality Development. International Review of Management and Marketing. Vol. 6 No. S8. Pp.119-124. (2016).

[33] Tahir Ibn Achour. Treaties on Maqasid al-Shariyyah, Trans. Mohamed el-Tahir elMesawi, United States of America: International Institute of Islamic Thought. (2006).

[34] Taqi al-Din Ahmad Ibn Taymiyyah. Dar' Ta'aruc̣ al-'Aql wal-Naql, M. R. Salim. Eds, Riyadh: Saudi Arabia. (1981). 